\title{
Towards the total synthesis of chondrochloren A: synthesis of the (Z)-enamide fragment
}

\author{
Jan Geldsetzer ${ }^{1}$ and Markus Kalesse ${ }^{* 1,2,3}$
}

\section{Full Research Paper}

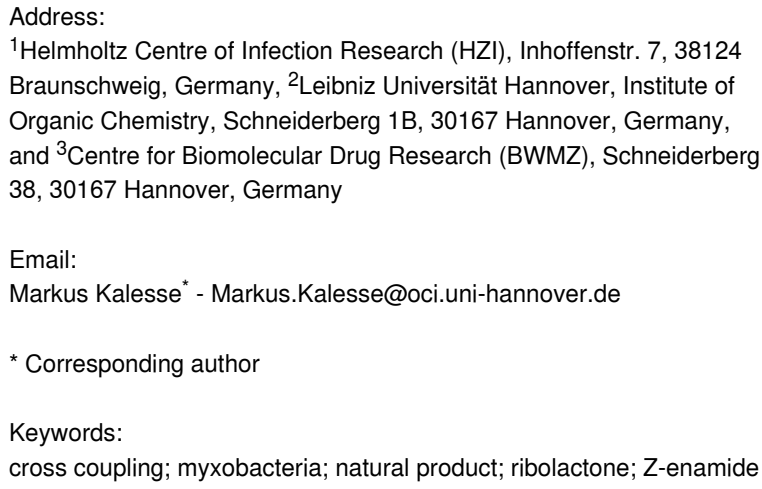

${ }^{1}$ Helmholtz Centre of Infection Research (HZI), Inhoffenstr. 7, 38124 Braunschweig, Germany, ${ }^{2}$ Leibniz Universität Hannover, Institute of Organic Chemistry, Schneiderberg 1B, 30167 Hannover, Germany, and ${ }^{3}$ Centre for Biomolecular Drug Research (BWMZ), Schneiderberg 38, 30167 Hannover, Germany

Email:

Markus Kalesse* - Markus.Kalesse@oci.uni-hannover.de

* Corresponding author

Keywords:

cross coupling; myxobacteria; natural product; ribolactone; Z-enamide

Beilstein J. Org. Chem. 2020, 16, 670-673.

doi:10.3762/bjoc. 16.64

Received: 04 February 2020

Accepted: 31 March 2020

Published: 14 April 2020

Associate Editor: B. Nay

(C) 2020 Geldsetzer and Kalesse; licensee Beilstein-Institut. License and terms: see end of document.

\begin{abstract}
The stereoselective synthesis of the $(Z)$-enamide fragment of chondrochloren (1) is described. A Buchwald-type coupling between amide $\mathbf{3}$ and ( $Z$ )-bromide $\mathbf{4}$ was used to generate the required fragment. The employed amide $\mathbf{3}$ comprising three chiral centers was obtained through a seven-step sequence starting from D-ribonic acid-1,4-lactone. The ( $Z$ )-vinyl bromide 4 is accessible in four steps from 4-hydroxybenzaldehyde. The pivotal cross coupling between both fragments was achieved after extensive experimentation with copper(I) iodide, $\mathrm{K}_{2} \mathrm{CO}_{3}$ and $N, N^{\prime}$-dimethylethane-1,2-diamine.
\end{abstract}

\section{Introduction}

In the course of our program to provide synthetic access to biologically active natural products we targeted complex polyketides and depsipetides [1-10]. One particular group of compounds of particular focus in our research activities are natural products with enamide moieties [11]. Among these, chondrochloren having a $(Z)$-enamide moiety features a rare structural motif. The myxobacterial metabolite chondrochloren A (1) was isolated from Chondromyces crocatus ( $\mathrm{Cmc5}$ ) by the groups of Höfle and Reichenbach in 2003 [12]. This PKS/ NRPS-derived natural product shows only weak antibiotic effects in agar diffusion tests against Micrococcus luteus, Schizosaccharomyces pombe, Bacillus subtilis and Staphylo- coccus aureus [12]. The relative and absolute stereochemistry of the molecule was elucidated by a combination of NMR, UV and IR spectroscopy and molecular dynamics calculations (MD, MM2) [12]. However, its (Z)-enamide motif and the polyoxygenated middle segment are synthetically challenging.

\section{Results and Discussion \\ Synthesis of amide 3}

Here we report our investigations on the construction of the segments 3 and $\mathbf{4}$ as well as our results on the cross coupling between both fragments. Our retrosynthetic approach (Figure 1) divides chondrochloren A (1) into three fragments of similar 


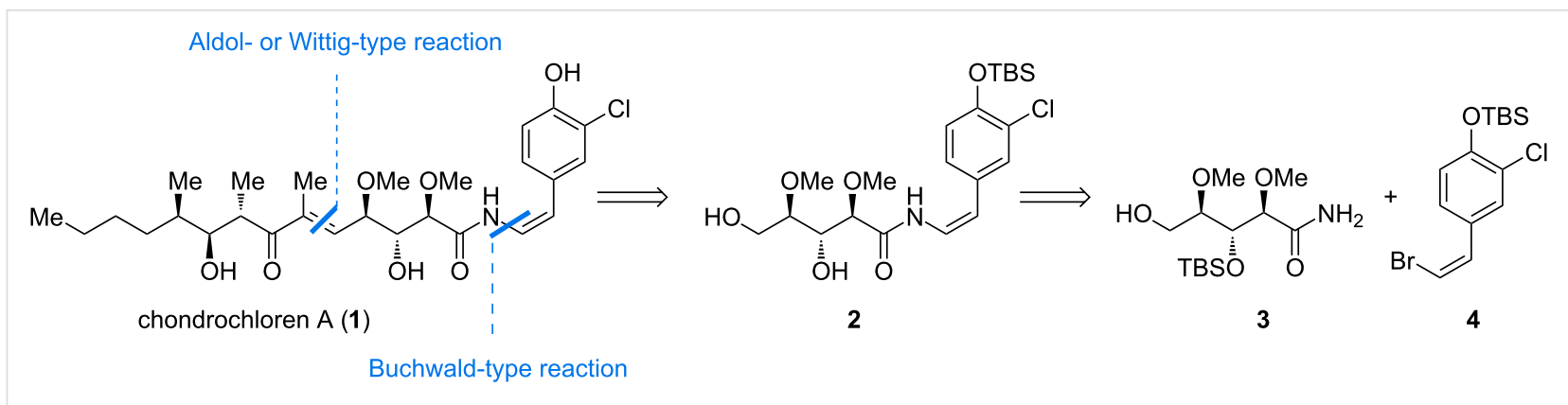

Figure 1: Retrosynthetic analysis of chondrochlorene A (1).

complexity: amide $\mathbf{2},(Z)$-bromide $\mathbf{4}$ and amide $\mathbf{3}$. For the coupling of amide $\mathbf{3}$ and $(Z)$-bromide $\mathbf{4}$ we decided to use a (Z)selective Buchwald-type reaction encouraged by the previous works of the Buchwald group on producing $(E)$-enamide coupling products [13-15].

The synthesis of the amide 3 started with TIPDS-protection of commercially available D-ribonic acid-1,4-lactone (5) (Scheme 1). A subsequent transesterification under mild conditions with $\mathrm{Bu}_{2} \mathrm{SnO}$ provided dihydroxy ester 7 in $72 \%$ yield. The 1,3-diol in $\mathbf{7}$ was methylated with an excess of the Meerwein reagent and TIPDS-removal afforded ester 9 in good yields. A double TBS-protection and liberation of the primary alcohol provided alcohol $\mathbf{1 1}$ in an excellent yield which was subjected to aminolysis to provide amide $\mathbf{3}$ in seven steps and an overall yield of $16 \%$ [16-20].

\section{Synthesis of (Z)-bromide 4}

For the synthesis of (Z)-bromide 4 we chose a palladiumcatalyzed, stereoselective dehalogenation as the key step (Scheme 2). Therefore, 4-hydroxybenzaldehyde (12) was chlorinated and phenol 13 was protected as TBS ether to afford aldehyde $\mathbf{1 4}$ which was then converted into dibromoolefine $\mathbf{1 5}$ in good yields using the Corey-Fuchs protocol. Uenishi et al.<smiles>O=C1O[C@H](CO)[C@@H](O)[C@H]1O</smiles>

TIPDSCl$_{2}$, imidazole 4 Å molecular sieves $\mathrm{DMF}, 0^{\circ} \mathrm{C}, 5 \mathrm{~min}$ $33 \%$

5<smiles>CC(C)[Si]1(C(C)C)OC[C@H]2OC(=O)[C@H](O)[C@H]2O[Si](C(C)C)(C(C)C)O1</smiles>

\section{$\mathrm{Bu}_{2} \mathrm{SnO}$ \\ $\mathrm{MeOH}, 65^{\circ} \mathrm{C}$}

$3 \mathrm{~h}, 72 \%$

$\stackrel{\mathrm{HF} \cdot 3 \mathrm{Et}_{3} \mathrm{~N}, \mathrm{Et}_{3} \mathrm{~N}}{\longrightarrow}$

THF, rt, $3 \mathrm{~h}$

$83 \%$<smiles>COC(=O)[C@H](O)[C@@H]1O[Si](C(C)C)(C(C)C)OC[C@@H](O)[C@H]1O[Si](C)(C)C(C)C</smiles>

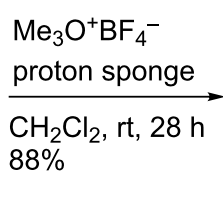<smiles>COC(=O)C(OC)[C@H]1O[Si](C(C)C)(C(C)C)OC[C@@H](OC)[Si](C(C)C)(C(C)C)O1</smiles><smiles>COC(=O)C(OC)[C@@H](O)[C@H](CO)OC</smiles>

9

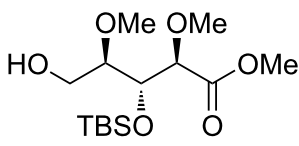

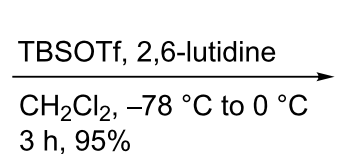
$3 \mathrm{~h}, 95 \%$

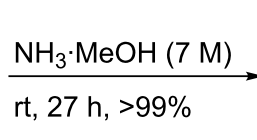

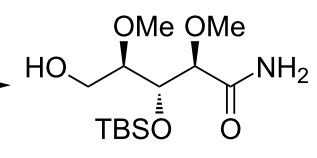

3

Scheme 1: Synthesis of amide 3 [16-20]. TIPDSCl $2=1,3$-dichloro-1,1,3,3-tetraisopropyldisiloxane, TBSOTf = tert-butyldimethylsilyl trifluoromethanesulfonate, proton sponge $=1,8$-bis $(N, N$-dimethylamino $)$ naphthalene. 


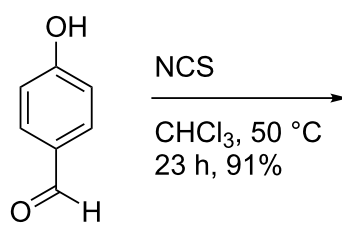

12<smiles>O=Cc1ccc(O)c(Cl)c1</smiles>

13

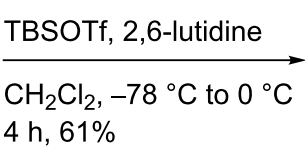

$4 \mathrm{~h}, 61 \%$<smiles>COc1ccc(C=O)cc1Cl</smiles>

14

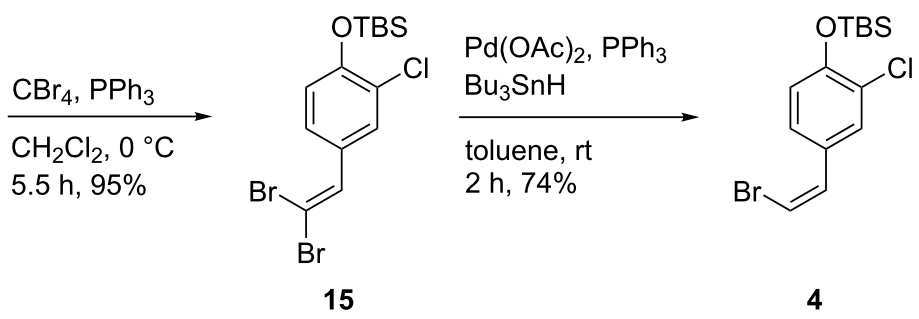

Scheme 2: Synthesis of (Z)-bromide 4 using a palladium-catalyzed, stereoselective dehalogenation [21-24]. TBSOTf = tert-butyldimethylsilyl trifluoromethanesulfonate, NCS $=N$-chlorosuccinimide, 2,6-lutidine $=2,6$-dimethylpyridine .

[21] published an effective way of defunctionalizing dihalogenated double bonds into the corresponding $(Z)$-monohalogenated derivatives using palladium(II) acetate, triphenylphosphine and tributyltin hydride. Following this procedure, we were able to obtain $(Z)$-bromide $\mathbf{4}$ in four steps and an overall yield of $39 \%$ [21-24].

\section{Cross coupling of fragments 3 and $\mathbf{4}$}

The formation of the ( $Z$ )-enamide should occur in a copper-catalyzed Buchwald-type reaction (Scheme 3). Based on a previous work of Buchwald and his group [13], we decided to use copper(I) iodide and $N, N^{\prime}$-dimethylethylenediamine (DMEDA) as the catalytic system in THF, which was reported to be the solvent of choice in this type of coupling reaction. Potassium carbonate was chosen due to the sensitivity of the amide 3 towards harsh basic conditions. With these conditions we were able to couple $(Z)$-bromide $\mathbf{4}$ with amide $\mathbf{3}$ selectively to yield $(Z)$-enamide 16. The obtained double bond geometry was confirmed by the indicative NMR coupling constants of $9.6 \mathrm{~Hz}$. Moreover, we observed a concentration dependent formation of the undesired desilylated $(Z$ )-enamide 17 (Table 1). The best results were achieved using a $65 \mathrm{mM}$ solution of the amide 3. Using dry potassium carbonate, purified copper(I) iodide provided the best results for the cross-coupling reaction.

\begin{tabular}{|c|c|c|c|c|}
\hline entry & $c$ (amide $3, \mathrm{mM}$ ) & 16 & 17 & 3 \\
\hline 1 & 20 & 33 & - & 31 \\
\hline 2 & 65 & 42 & 11 & - \\
\hline 3 & 136 & 3 & 11 & 2 \\
\hline 4 & 140 & 17 & 27 & - \\
\hline
\end{tabular}

aConditions: amide 3 (1.0 equiv), ( $Z$ )-bromide 4 (1.0 equiv), DMEDA ( 0.60 equiv), Cul ( 0.30 equiv), THF, $65^{\circ} \mathrm{C}$. DMEDA $=N, N^{\prime}-$ dimethylethylenediamine.

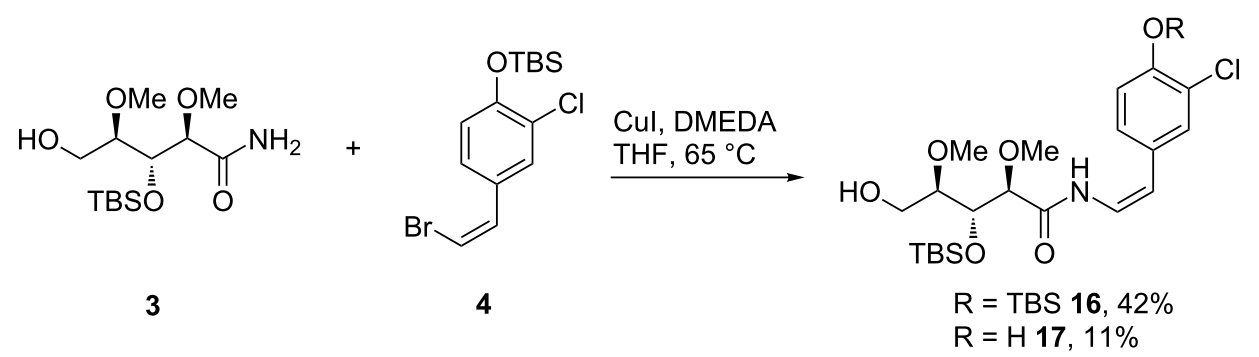




\section{Conclusion}

In summary, we established a $(Z)$-selective Buchwald-type coupling reaction as a key step in the synthesis of an advanced fragment of chondrochloren A (1). The required amide 3 can be synthesized in seven steps with a $16 \%$ overall yield [16-20], whereas the (Z)-bromide $\mathbf{4}$ can be generated in a four-step sequence with a $39 \%$ overall yield, including a palladiumcatalyzed, stereoselective dehalogenation [21-25].

\section{Supporting Information}

\section{Supporting Information File 1}

Experimental procedures and spectral data of the synthesized compounds.

[https://www.beilstein-journals.org/bjoc/content/ supplementary/1860-5397-16-64-S1.pdf]

\section{Acknowledgements}

We thank Sarah Hoffmann for assistance with the manuscript preparation.

\section{Funding}

We are grateful to the DFG (Ka913/24-1) and the graduate school MINAS for funding this research.

\section{ORCID ${ }^{\circledR}$ iDs}

Jan Geldsetzer - https://orcid.org/0000-0002-4155-7329

Markus Kalesse - https://orcid.org/0000-0003-4858-3957

\section{References}

1. Kalesse, M.; Chary, K. P.; Quitschalle, M.; Burzlaff, A.; Kasper, C.; Scheper, T. Chem. - Eur. J. 2003, 9, 1129-1136. doi:10.1002/chem.200390130

2. Ehrlich, G.; Hassfeld, J.; Eggert, U.; Kalesse, M. J. Am. Chem. Soc. 2006, 128, 14038-14039. doi:10.1021/ja0659572

3. Ehrlich, G.; Hassfeld, J.; Eggert, U.; Kalesse, M. Chem. - Eur. J. 2008, 14, 2232-2247. doi:10.1002/chem.200701529

4. Brodmann, T.; Janssen, D.; Kalesse, M. J. Am. Chem. Soc. 2010, 132, 13610-13611. doi:10.1021/ja107290s

5. Hartmann, O.; Kalesse, M. Org. Lett. 2012, 14, 3064-3067. doi:10.1021/ol3011387

6. Hartmann, O.; Kalesse, M. Angew. Chem., Int. Ed. 2014, 53, 7335-7338. doi:10.1002/anie.201402259

7. Gieseler, M. T.; Kalesse, M. Org. Lett. 2014, 16, 548-551. doi:10.1021/ol403423r

8. Gerstmann, L.; Kalesse, M. Chem. - Eur. J. 2016, 22, 11210-11212. doi:10.1002/chem.201602682

9. Poock, C.; Kalesse, M. Org. Lett. 2017, 19, 4536-4539. doi:10.1021/acs.orglett.7b02112

10. Lücke, D.; Linne, Y.; Hempel, K.; Kalesse, M. Org. Lett. 2018, 20 4475-4477. doi:10.1021/acs.orglett.8b01768
11. Rentsch, A.; Kalesse, M. Angew. Chem., Int. Ed. 2012, 51, 11381-11384. doi:10.1002/anie.201206560

12. Jansen, R.; Kunze, B.; Reichenbach, H.; Höfle, G. Eur. J. Org. Chem 2003, 2684-2689. doi:10.1002/ejoc.200200699

13. Jiang, L.; Job, G. E.; Klapars, A.; Buchwald, S. L. Org. Lett. 2003, 5, 3667-3669. doi:10.1021/ol035355c

14. Martín, R.; Cuenca, A.; Buchwald, S. L. Org. Lett. 2007, 9, 5521-5524. doi:10.1021/ol7024718

15. Kuranaga, T.; Sesoko, Y.; Inoue, M. Nat. Prod. Rep. 2014, 31, 514 doi:10.1039/c3np70103d

See for Cu-mediated enamide formations in the total synthesis of complex peptide natural products.

16. Cen, Y.; Sauve, A. A. J. Am. Chem. Soc. 2010, 132, 12286-12298. doi:10.1021/ja910342d

17. Hildbrand, S.; Blaser, A.; Parel, S. P.; Leumann, C. J. J. Am. Chem. Soc. 1997, 119, 5499-5511. doi:10.1021/ja9704904

18. Baumhof, P.; Mazitschek, R.; Giannis, A. Angew. Chem., Int. Ed. 2001, 40,3672 doi:10.1002/1521-3773(20011001)40:19<3672::aid-anie3672>3.0.co;2$\mathrm{y}$

19. Schläger, N.; Kirschning, A. Org. Biomol. Chem. 2012, 10, 7721. doi:10.1039/c2ob26185e

20. Uenishi, J.; Kawahama, R.; Yonemitsu, O.; Tsuji, J. J. Org. Chem. 1998, 63, 8965-8975. doi:10.1021/jo9812781

21. Rama Rao, A. V.; Chakraborty, T. K.; Laxma Reddy, K.; Srinivasa Rao, A. Tetrahedron Lett. 1994, 35, 5043-5046. doi:10.1016/s0040-4039(00)73315-6

22. Symkenberg, G.; Kalesse, M. Angew. Chem., Int. Ed. 2014, 53, 1795-1798. doi:10.1002/anie.201309386

23. Oppolzer, W.; Birkinshaw, T. N.; Bernardinelli, G. Tetrahedron Lett. 1990, 31, 6995-6998. doi:10.1016/s0040-4039(00)97225-3

24. Shen, R.; Porco, J. A. Org. Lett. 2000, 2, 1333-1336. doi:10.1021/ol005800t

25. Yang, X.; Liu, H.; Fu, H.; Qiao, R.; Jiang, Y.; Zhao, Y. Synlett 2010, 101-106. doi:10.1055/s-0029-1218530

\section{License and Terms}

This is an Open Access article under the terms of the Creative Commons Attribution License (http://creativecommons.org/licenses/by/4.0). Please note that the reuse, redistribution and reproduction in particular requires that the authors and source are credited.

The license is subject to the Beilstein Journal of Organic Chemistry terms and conditions: (https://www.beilstein-journals.org/bjoc)

The definitive version of this article is the electronic one which can be found at: doi:10.3762/bjoc. 16.64 